\title{
SECTORAL STRUCTURE CHANGE MODELING OF EUROPEAN OIL AND GAS PRODUCING COUNTRY'S ECONOMY
}

\author{
Viacheslav Alexandrovich Perepelkin; Elena Viacheslavovna Perepelkina \\ Samara State University of Economics, Russia
}

DOI 1515/eoik-2015-0017, UDK 339.923:656.2(497)

Original scientific paper

\section{ABSTRACT}

In this paper, we consider identifying features of sectoral structuring within the national economy that has definite foreign trade product specialization. Examination of the sector-specific division methodology enabled identification of its strong association with certain sector dominance in the economy. It is against this background that we offer an explanation for the delay in transferring from the post-Soviet to the applicable international classification of economic structure elements in Russia and Belarus. We perform analysis of the three-component $P-S-T$ model (primary, secondary, tertiary sector) using statistical and econometric methods and define properties of the sectoral shares dynamics in national economies of oil and gas producing countries. Analysis of the Russian and Norwegian economies' intersectoral changes suggests that it is necessary for the government to develop and implement selective structural policy to overcome the existing structural disproportions.

Keywords: sector, intersectoral shift, minerals extraction, deindustrialization, tertiarization.

\section{INTRODUCTION}

Driven by traditional resources scarcity, replacement of material production factors by human capital and consumption shift to non-material goods, global structural transformation requires from developed national economies achievement of new economic growth quality corresponding to the post-industrial society. It may be that one of the obstacles to that is the natural resources exploitation-oriented sector, if it causes an outflow of significant economic resources volume from other sectors due to its financial attractiveness and high capital intensiveness.
The model of structural development, under which the impact of material component of economic growth is consistently reducing, is based on the economy's division into primary, secondary and tertiary sectors (P-S-T model) proposed by Fischer (1939;1952), Fourastie (1949), Clark (1940) and Wolfe (1955). Playing a major role in explanation of empirically observed shift to post-industrial society (Dietrich \& Krüger, 2010), this three-sectoral model differs from dividing the economy into agriculture, industry and services developed by Kuznets (1971) (A-I-S model) - primarily by separation of subsoil assets extraction from industry and including it into the primary sector. Commitment of some Eastern European statistical agencies to S. Kuznets model - still existing a few years ago - was determined to a high extent by the wish to present economies of those countries less resource based and more industrial.

Chenery and Taylor (1968) in their sector growth analysis function relate mining to the primary sector. They explained the possibility of typologization of the economy's structural transformation process for different groups of countries by universal and specific factors influence. Indicators of raw materials extraction and export along with characteristics of production conditions, aggregate demand, and investment activity belong to the indicators of universal factors influence in Chenery's hypothesis.

Pasinetti $(1981 ; 1993)$ considered learning by doing - which takes place through observation, experimentation, action, mutual knowledge exchange as well as learning new behavior patterns - as the major reason for growth and change in the economy structure (Arrow, 1962; Romer, 1986; Young, 1993). New sectors appearance and old sectors disappearance in his theory is caused by innovations - production innovations in particu- 
lar that are supported by change of consumption structure due to real incomes growth stimulated by technological innovations. Over time, technological innovations transfer to different sectors and branches, whereas production innovations stay where they originated. Transiting from positive to normative analysis, Pasinetti paid attention to the problem of structural shifts combination and equilibrium establishment. From the perspective of the economy theory development, it is important that the constantly occurring structural changes may not be construed as an obstacle to harmonious process of growth and adjustment to equilibrium.

Explanation concerning deviations from the post-industrial trend of tertiarization sectoral development is often given in terms of Tadeush M. Rybczynski's theorem (Rybczynski, 1955), according to which there is a direct interrelation between the production factors growth in some parts of economy and depression and even recession in others - due to limited resources. The case when positive results from production expansion and increase in export in one sector or branch are less significant than negative consequences for the economy itself (in particular, deindustrialization begins) was termed immiserizing growth (Bhagwati, 1958). Description of partial deindustrialization of the Netherlands economy with the increase in natural gas extraction was made in 1981 by Ellman (1981) as well as other authors and was later referred to in the literature as 'Dutch Disease' (Dülger, Lopcu, Burgaç \& Balli, 2013; Cherif, 2013). The goal of Resource Curse elimination remains crucial for a wide range of countries and scientists (Cheng, Sachs, \& Yang, 2004; Bjorvatn, Farzanegan \& Schneider, 2012) actively discussing the related challenges. The central problem of conducted research is substantiation of necessity of governmental selective structural policy directed at overcoming dependence on raw materials export for countries with different levels of socioeconomic development.

This paper consists of the following parts. Section 2 'Models of division of economy into sectors and their usage in classificators of structural elements of economy' briefly describes models of economy structuring in the industrial and post-industrial society as well as explains reasons of delay in shifting from the first to the second one by development of classificators of structural elements in economies of Russia and Belarus. Section 3 'Analysis of consequences of introduction of classificators of economic activity types in Russia and Belarus' discusses consequences of introducing Russian and Belorussian types of economic activity classificators. Section 4 'Changes in sectoral structure of the Russian and Norwegian economies in the 2000s' evaluates changes occurred in Russia in the 2000s on the basis of its sectoral structure data, then follows a correlation with the Norwegian economy analogous data. In section 5 'Econometric model of intersectoral shifts in the economies of Russia and Norway', we present econometric model of sectoral shifts in the economies under consideration and interpret its results.

\section{MODELS OF DIVISION OF ECONOMY INTO SECTORS AND THEIR USAGE IN CLASSIFICATORS OF STRUCTURAL ELEMENTS OF ECONOMY}

First versions of ISIC and NACE introduced in 1960-1970s were generally in line with the sectoral division of the economy into agriculture, industry and services formulated by Kuznets (1971). At the same time, the problem of noncontradictory description of economy's sectoral structuring criteria emerged. The necessity of solving this problem is still noted: 'The division into components must have an analytical basis; 'sectors' must differ significantly from each other. With new technologies much of what used to be 'services' is becoming part of what used to be 'manufacturing', and much of employment growth in services reflects contracting out (outsourcing) of work previously done by manufacturing' (Syrquin, 2010). Unavailability of accurate differentiation between the sector based on natural resources exploitation and the sector of raw materials processing manifested itself firstly in attributing the whole output of minerals to industry, which was justified by absence of seasonality in operation of mining enterprises as well as their similarity to industrial enterprises concerning organization of manufacturing.

Expansion of the industry sphere by breaking down the national economy into sectors in accord- 
ance with the A-I-S (agriculture-industry-services) model slightly improves the inter- and intrasectoral picture of underdeveloped and developing countries. This model of sectoral structure looks particularly appealing to governments of countries that are rich in fossil fuels and exploit them actively. The classification of branches system by subject of their activity (OKONH) - introduced by the USSR Gosstandart (State Committee for Standardization) in November 1975 - was not accidentally similar to the A-I-S model. After the USSR disintegration, it was applied without any major modifications to statistical systems of almost all the CIS (Commonwealth of Independent States) countries, in Russia and Belarus - under the same abbreviation. In accordance with OKONH methodology, economy was divided into (i) material production sphere, where national product (production of goods and services of industrial use) was created, and (ii) non-production sphere, which, as it was supposed, created neither national product nor national income. The non-production sphere incorporated other branches of the service sector. Natural resources extraction was included into industry. For instance, processing and extraction of ore were parts of the ferrous and non-ferrous metallurgy.

Because of using a broad definition of the industrial sphere branches composition, statistical agencies and state administration bodies had to deal with a huge heterogeneous aggregate called 'industry'. It was difficult to control, though simple to conceal insufficient effectiveness and competitiveness of processing industries with explicit and implicit transfers from the so-called 'primary industry'. Major channels of such transfers' receipt in Russia are energy prices (being significantly lower vs. world prices), non-market trade barter agreements, price-freeze agreements, and agreements on mutual direct deliveries at underestimated prices.

Introduced in January 2008, All-Russian Classifier of Types of Economic Activity (OKVED) (Rosstat, 2012) and in January 2011 All-State Classification of Economic Activity (OKED) (Belstat, 2012) should serve - along with the state statistical observation of economic processes development - the purpose of preparing statistical facts and figures for comparisons at the international level. Therefore, these classificators were developed 'on the basis of bringing to conformity with the official Russian version of NACE Rev. 1.1 (Rosstat, 2012) by including the last into OKVED 2007 and OKED. Since 2008 however, statistical agencies of the EU countries passed to NACE Rev. 2 (Eurostat, 2013). It prevented Russian and Belorussian classificators from achieving desired identity with the European classification. Furthermore, OKVED and OKED reflect features of Russian and Belorussian economies by using lower levels groupings absent in the European classification (Table 1): in OKVED these are five-unit codes subgroups making up the fifth level as well as making up the sixth level and having six-unit codes types; in OKED these are subclasses representing the fifth level and being numerated by five-unit codes. Though numbers of subgroups in OKVED and subclasses in OKED at the fifth level are equal, the structure of their distribution by economy sectors is different.

Table 1

Distribution of number of subclasses in OKED, subgroups and types in OKVED by economic sectors

\begin{tabular}{lccc}
\hline \multirow{2}{*}{ Sector } & \multicolumn{3}{c}{$\begin{array}{c}\text { Classificator, } \\
\text { fifth level groupings }\end{array}$} \\
\cline { 2 - 4 } & OKED & OKVED & type \\
\cline { 2 - 4 } & subclass & 55 & 38 \\
\hline Primary & 48 & 334 & 113 \\
\hline Secondary & 396 & 379 & 241 \\
\hline Tertiary & 324 & 768 & 392 \\
\hline Total number & 768 & & subgroup \\
\hline
\end{tabular}

Source: Belstat (2012); Rosstat (2012) 
Differences in distribution by sectors of the same level subgroups in OKVED and subclasses in OKED are apparently linked to dissimilar sectoral structures of the Russian and Belorussian economies. Leading role of minerals extraction in the Russian economy predetermined the fact that the number of subgroups exceeds the number of subclasses by 7 in the primary sector. Greater share of processing industries in the GDP and employment structure of the Belorussian economy resulted in the number of subclasses exceeding the number of subgroups by 62 in the secondary sector. In the tertiary sector, the number of subclasses is by 55 less than the number of subgroups, which is an evidence of retardation of the Belorussian economy in progress on the tertiarization path.

The abovementioned differences in distributing statistical positions number by economic sectors in Russia and Belarus reflect an unusual situation, in which a country with much smaller economy uses more profound detalization of statistical data within such a big sector as the secondary one. This feature of statistical methodology applicable in Belarus can be considered as a consequence of the As-Is State of the economy's sectoral structure and the country's government perception of the general direction of structural economic development in the future.

\section{ANALYSIS OF CONSEQUENCES OF INTRODUCTION OF CLASSIFICATORS OF ECONOMIC ACTIVITY TYPES IN RUSSIA AND BELARUS}

Transition from OKONH (pursuant to which an enterprise is the target of branch affiliation definition and the object of administration) to OKVED (based on standards adopted from the developed market system) implies changes in the state economy regulation: influencing conditions of performing a certain economic activity type ministry or office is entitled to apply a regulatory function with regard to the whole range of enterprises carrying out this activity (not to each of these enterprises separately though). An example of Belarus, where substitution of OKONH for OKED occurred with considerable delay compared to Russia, gives evidence of difficulty in truly successful problem solution in respect of statistics reform under conditions, when even official data suggest that the private enterprises share does not exceed $40 \%$.

Table 2

Average annual structure of GDP and gross value added by sectors of the Russian economy over $2002-2004, \%$

\begin{tabular}{lccccc}
\hline \multicolumn{2}{c}{$\begin{array}{c}\text { In accordance with structure of } \\
\text { economy sectors by OKONH }\end{array}$} & \multicolumn{2}{c}{ In accordance with structure of types of economic activity by } \\
OKVED
\end{tabular}

Source: Rosstat $(2013 ; 2014)$,

The relative service sector value in Table 2 is everywhere almost the same and equals approximately 59\%. The GDP sectoral structure definition based on OKONH slightly differs from the sectoral structure of gross value added calculated in accordance with OKVED and the A-I-S model: relative share of agriculture is by $1.17 \%$ less than the agrari- 
an one; the share of manufacturing, construction and other production output is by $0.5 \%$ bigger than the industrial sector share; the services production share exceeds the service sector share by $0.67 \%$. Greater differences are observed in the P-S-T model concerning the first two sectors' relative shares: the primary sector share is 2.18 times bigger vs. the agrarian sector and 2.65 times vs. agriculture; the secondary sector share appeared to be by $7.71 \%$ smaller than the industrial sector share and by $8.21 \%$ smaller than the share of manufacturing, construction and other production output. The Russian econ- omy structure calculated in accordance with the P-S-T model, remaining as service-intensive as previously, is more reliant on natural resources exploitation, but less overburdened with their processing.

\section{CHANGES IN SECTORAL STRUCTURE OF THE RUSSIAN AND NORWEGIAN ECONOMIES IN THE 2000s}

Strong structure-forming impact of minerals extraction on the Russian economy by usage of sectoral division as to the P-S-T model consists in growth of the primary sector relative value.

Table 3

Sectoral structure of gross value added in Russia in the 21 st century, \%

\begin{tabular}{lrrrrrrrrrrrrrrr}
\hline Sector & $\mathbf{2 0 0 0}$ & $\mathbf{2 0 0 1}$ & $\mathbf{2 0 0 2}$ & $\mathbf{2 0 0 3}$ & $\mathbf{2 0 0 4}$ & $\mathbf{2 0 0 5}$ & $\mathbf{2 0 0 6}$ & $\mathbf{2 0 0 7}$ & $\mathbf{2 0 0 8}$ & $\mathbf{2 0 0 9}$ & $\mathbf{2 0 1 0}$ & $\mathbf{2 0 1 1}$ & $\mathbf{2 0 1 2}$ & $\mathbf{2 0 1 3}$ & $\mathbf{2 0 1 4}$ \\
\hline $\mathbf{P}$ & 13,05 & 13,68 & 12,95 & 12,88 & 15,12 & 16,11 & 15,44 & 14,46 & 13,74 & 13,21 & 13,46 & 15,08 & 14,93 & 14,39 & 14,49 \\
\hline $\mathbf{S}$ & 28,3 & 26,79 & 26,19 & 25,95 & 26,83 & 26,93 & 26,31 & 26,38 & 26,78 & 25,11 & 25,1 & 26,72 & 25,98 & 25,59 & 25,5 \\
\hline $\mathbf{T}$ & 58,65 & 59,53 & 60,86 & 61,17 & 58,05 & 56,96 & 58,25 & 59,16 & 59,48 & 61,68 & 61,44 & 58,2 & 59,09 & 60,02 & 60,01 \\
\hline
\end{tabular}

Source: Rosstat $(2005 ; 2015)$

Strong structure-forming impact of minerals extraction on the Russian economy by usage of sectoral division as to the P-S-T model consists in growth of the primary sector relative value. In contrast to the picture of structural shifts described in the three sectors concept - where the primary sector is reduced to the utmost, the secondary sector displays the least reduction, while the tertiary sector grows - in the Russian economy in 2002-2007 the primary sector share grew by $1.41 \%$, the tertiary sector share - by $0.51 \%$, while the secondary sector share decreased by $1.92 \%$. Therefore, in years of comparatively fast economic growth a danger of deindustrialization of Russian economy did not arise from the service sector, as many believed. It was caused by the primary sector expansion in its part associated with fossil fuels extraction.

In this respect, the economic crisis in 2008-2009 and the following period of re- covery did not affect the Russian economy structural transformation: in 2008-2014, the primary sector share increased by $0.75 \%$; the secondary sector share decreased by $1.28 \%$; the tertiary sector share growth was $0.53 \%$. During the whole period from 2000 to 2014, it was observed an expansion of the primary sector by $1.44 \%$, while tertiary sector share grew by $1.36 \%$ and secondary sector share decreased by $2.8 \%$. Thus, expansion of the economic activity types associated with mining minerals remains the major driving force of sectoral shifts in the XXI c. Russian economy determining its basic structural characteristics in statics and dynamics. In the light of the above, in 2000-2014 the economy sectors' average shares were as follows: the primary sector $-14.2 \%$, the secondary sector $-26.3 \%$, the tertiary sector $-59.5 \%$.

Graph 1-3 show that secondary sector share tended to decline unlike primary and tertiary sector shares demonstrating a weak growth tendency. 


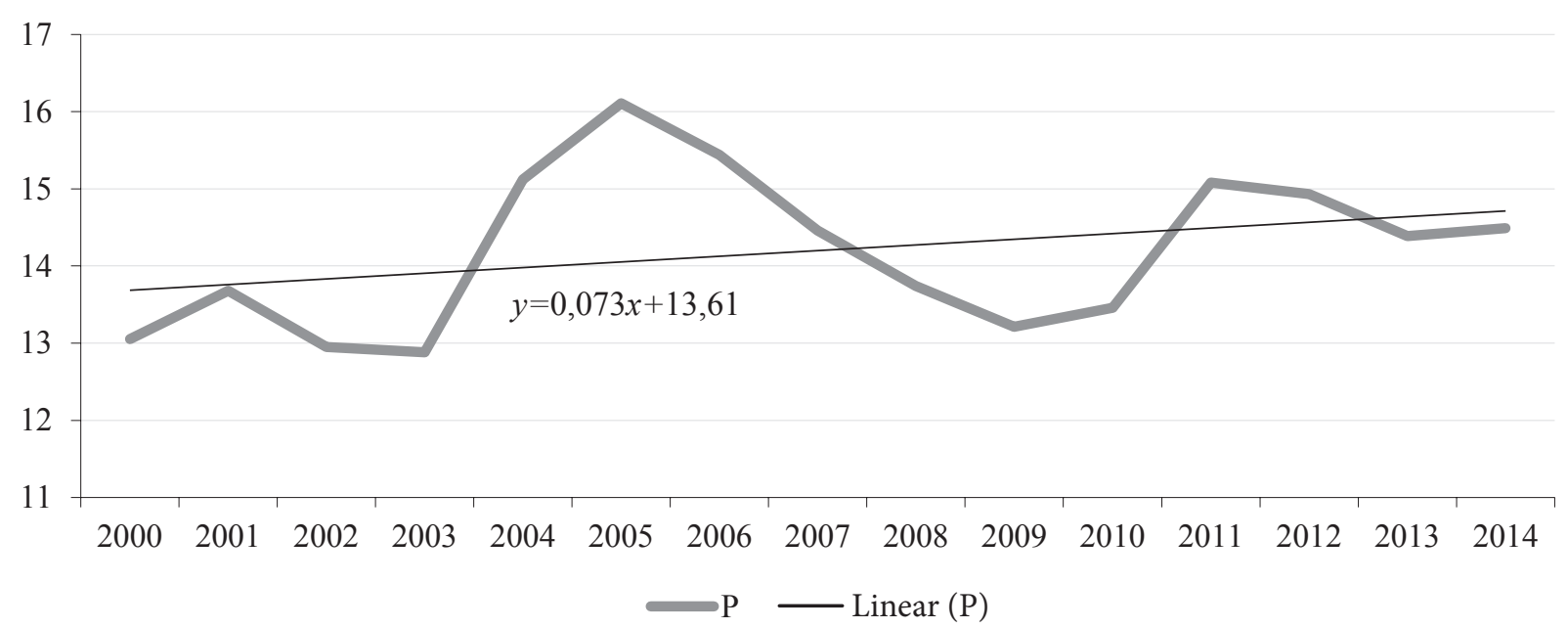

Graph 1. Trend of the Russian economy primary sector share

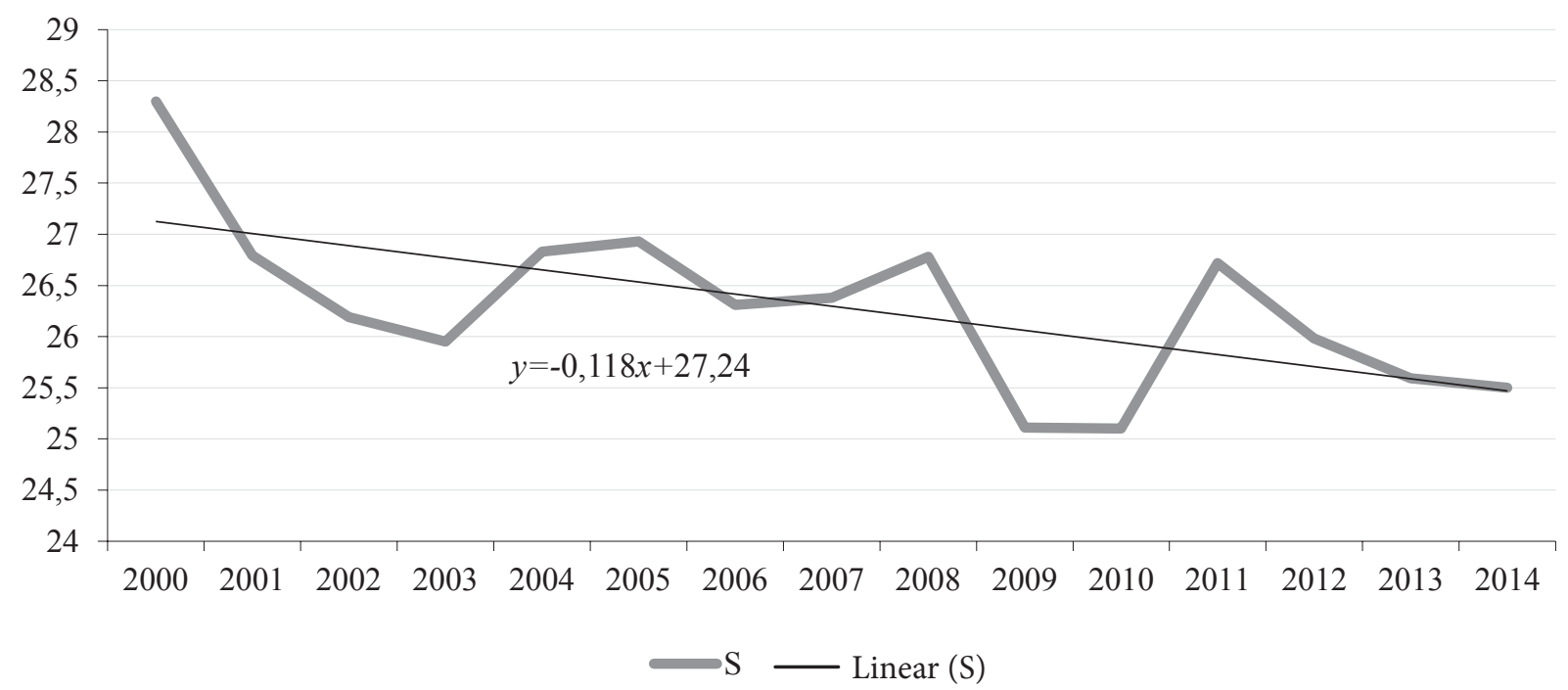

Graph 2. Trend of the Russian economy secondary sector share
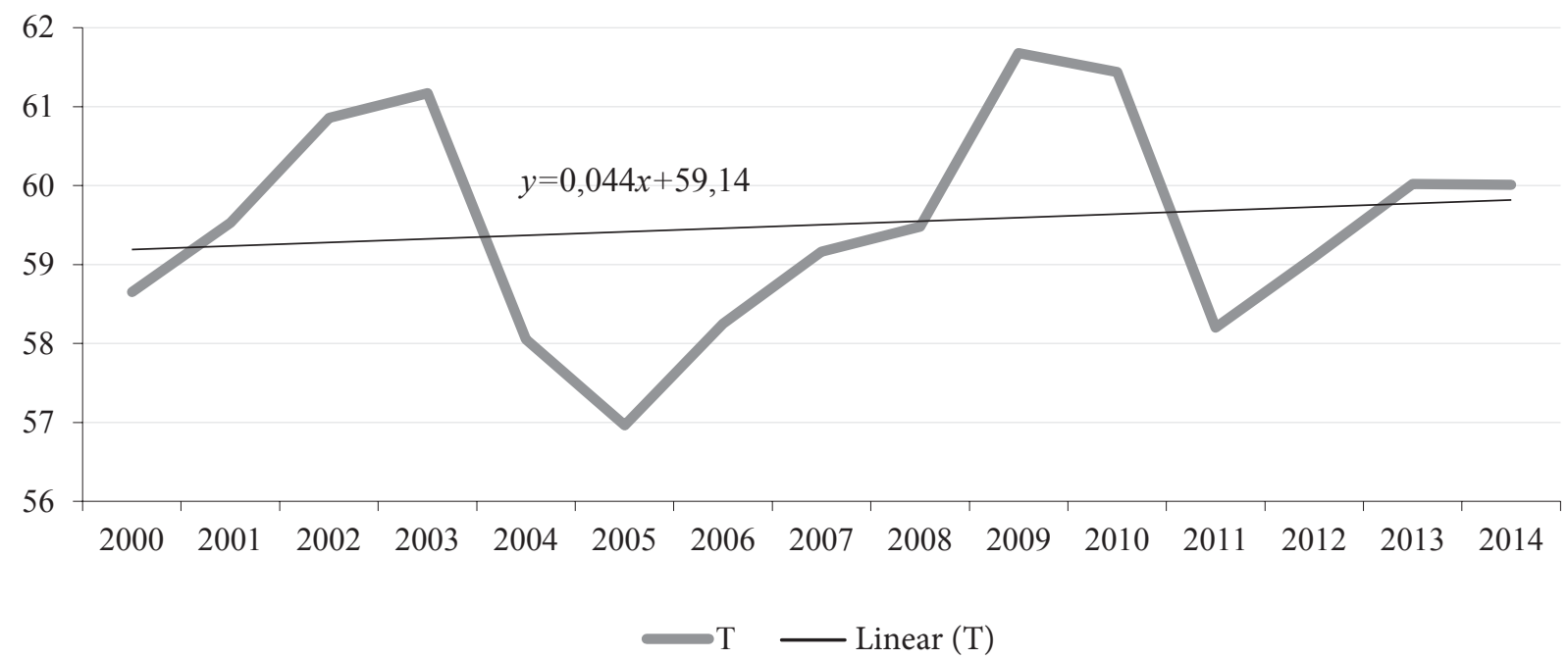

Graph 3. Trend of the Russian economy tertiary sector share 
Table 4

Sectoral structure of gross value added in Norway in the 21 st century, \%

\begin{tabular}{lrrrrrrrrrrrrrrr}
\hline Sector & $\mathbf{2 0 0 0}$ & $\mathbf{2 0 0 1}$ & $\mathbf{2 0 0 2}$ & $\mathbf{2 0 0 3}$ & $\mathbf{2 0 0 4}$ & $\mathbf{2 0 0 5}$ & $\mathbf{2 0 0 6}$ & $\mathbf{2 0 0 7}$ & $\mathbf{2 0 0 8}$ & $\mathbf{2 0 0 9}$ & $\mathbf{2 0 1 0}$ & $\mathbf{2 0 1 1}$ & $\mathbf{2 0 1 2}$ & $\mathbf{2 0 1 3}$ & $\mathbf{2 0 1 4}$ \\
\hline $\mathbf{P}$ & 26,83 & 24,05 & 20,61 & 26,61 & 22,94 & 26,61 & 28,32 & 25,32 & 28,99 & 21,08 & 22,95 & 24,02 & 25,08 & 23,57 & 21,87 \\
\hline $\mathbf{S}$ & 15,78 & 17,3 & 17,84 & 16,26 & 16,65 & 16,26 & 17,06 & 17,32 & 16,95 & 16,05 & 15,98 & 15,65 & 15,17 & 15,39 & 15,59 \\
\hline $\mathbf{T}$ & 57,39 & 58,65 & 61,55 & 57,13 & 60,41 & 57,13 & 54,62 & 57,36 & 54,06 & 62,87 & 61,07 & 60,33 & 59,75 & 61,04 & 62,54 \\
\hline
\end{tabular}

Source: Statistics Norway $(2005 ; 2009 ; 2011 ; 2013 ; 2014)$

The process of the Norwegian economy sectoral structure change over the reviewed period occurred intensively (Table 4). Over 14 years, only the tertiary sector share in gross value added of the country increased by $5.15 \%(3.8$ times much than increase in the Russian economy). At the same time, the primary sector share decreased by $4.96 \%$ and the secondary - by $0.19 \%$. Furthermore, the primary sector share in the Norwegian economy 1.5 times exceed- ed that share in the Russian economy showing stronger dependence on natural resources exploitation. Like the Russian tertiary sector, the Norwegian one had the greatest relative share in the economy (mean value $-59.06 \%$, or by $0,44 \%$ less than the Russian one), and its fluctuations were stronger. The primary sector share mean value was $24.59 \%$, which by $10.39 \%$ exceeded the Russian one. The secondary sector mean share equaled $16.35 \%$ (by $9.95 \%$ less).

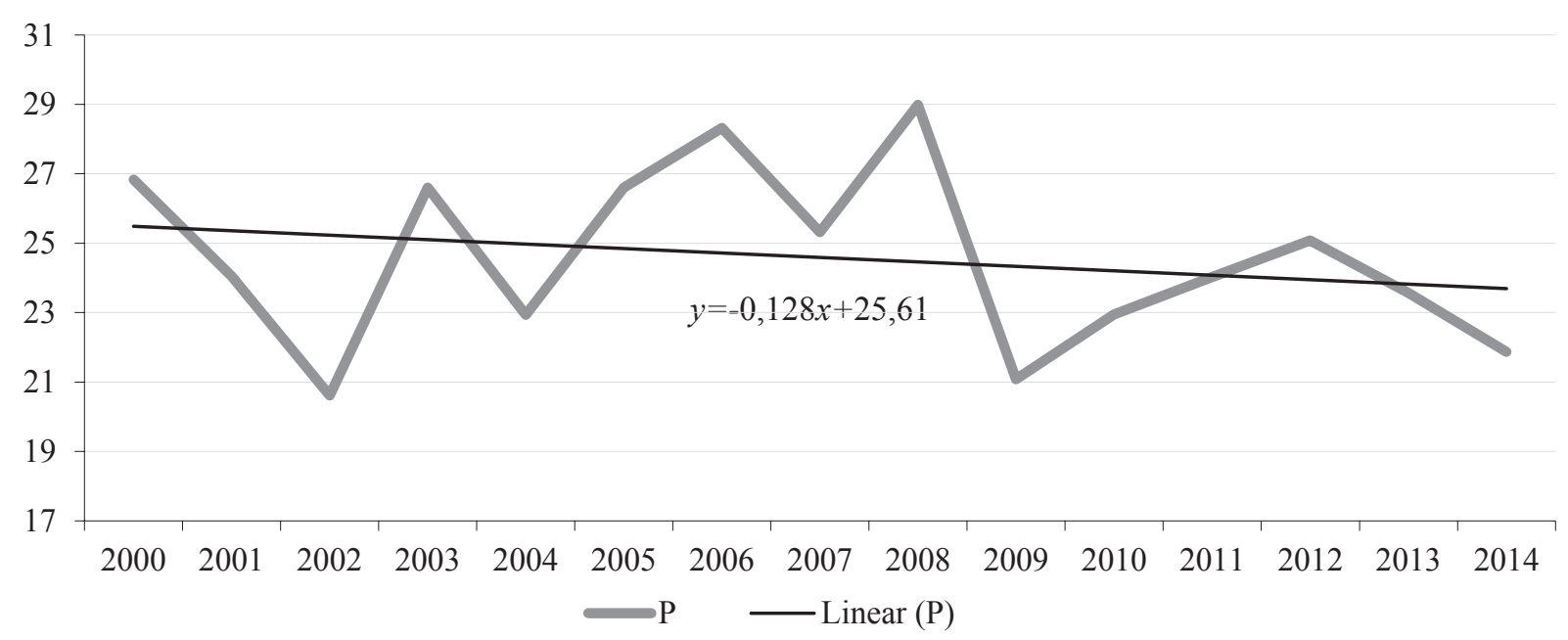

Graph 4. Trend of the Norwegian economy primary sector share

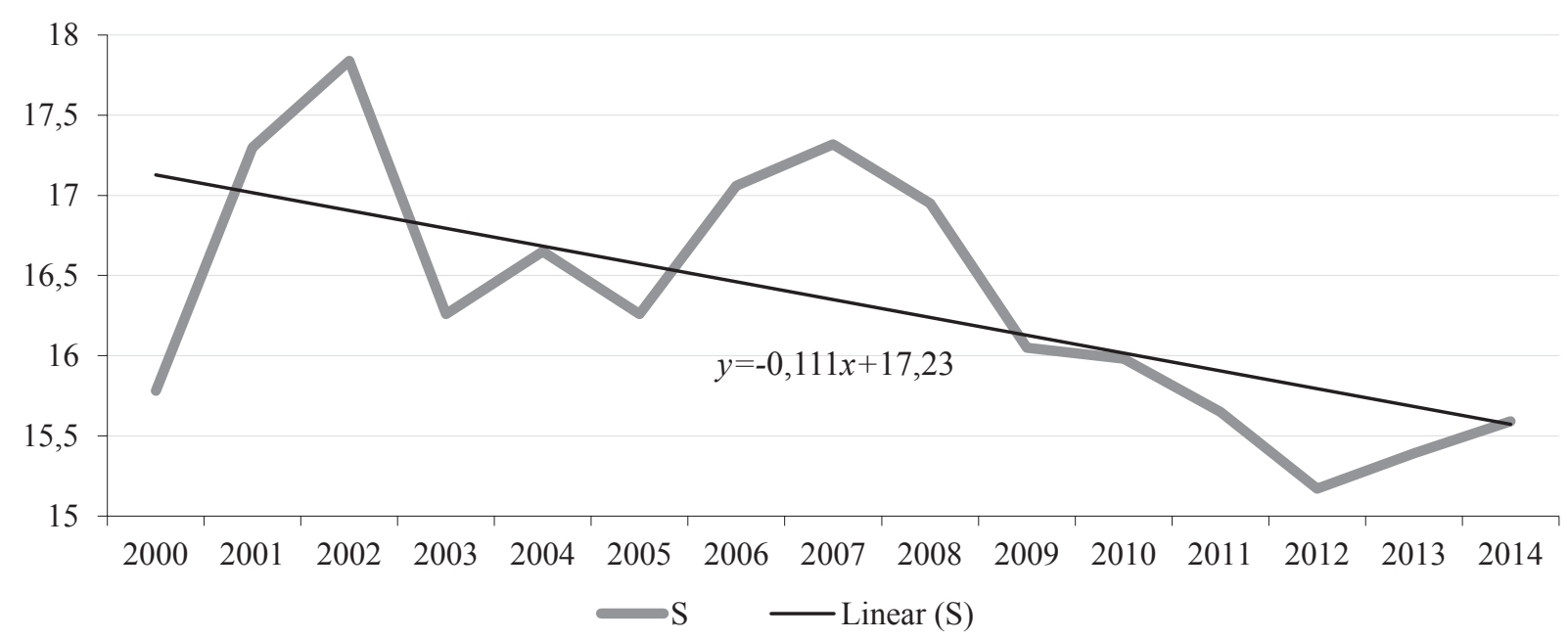

Graph 5. Trend of the Norwegian economy secondary sector share 


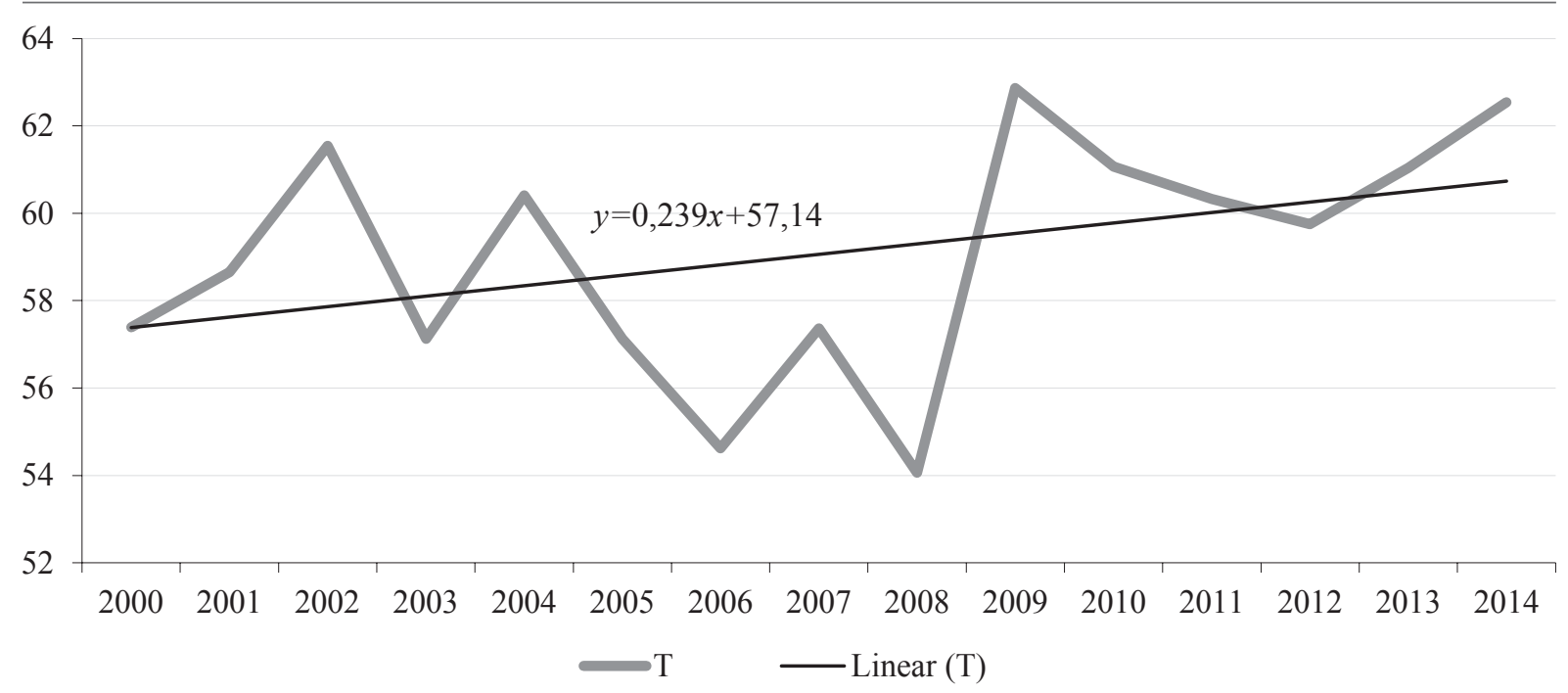

Graph 6. Trend of the Norwegian economy tertiary sector share

Graph 4-6 suggest that the secondary and tertiary sectors of the Russian and Norwegian economies have the same dynamics of their shares although deviations from the average in the Norwegian economy were more explicit than in the Russian one.

Introduction of measures applicable in the institutional and economic policy just slightly affected the negative intersectoral developments in the Scandinavian country' economy, demonstrating in this respect worse parameters of structural transformation comparing to Russia - both in dynamics and in statics. An example of an oil and gas producing OECD-member country developed market economy allows suggesting that without development and implementation of governmental selective structural policy possible future liberal economic reforms in Russia might not liberate the country from dominance of interests of faction in power associated with hydrocarbon raw materials exploitation.

The described sectoral growth asymmetry is evident from nonoptimal resource allocation as well as from income distribution inequality. The flow of 'petrodollars' from abroad, increasing positive income elasticity of demand for non-tradable goods, leads to growth of the prices for them. As in regard of most services applies uno-actu-prinzip (principle of coincidence of time and place of production and consumption of a service), many non-tradable on international markets services are created in tertiary sector. Consequently, the services prices are mainly determined by the domestic market situation, where excessive demand for them derives from the oil and gas incomes increase. In this respect, it is logical to expect partial moving of resources from the primary and secondary sectors (where mainly tradable goods are produced) into the tertiary sector producing goods with high income-related demand elasticity.

Special procedures of managing state income from oil export in Russia and Norway are adjusting the intersectoral shifts process. Artificial reduction of aggregate demand by 'sterilization' of excessive export revenue in stabilization funds is considered a proven method of preventing inflation and national economy's dependence on conjuncture fluctuations in the international raw material markets. However, domestic investment and state expenditures limitation in case of non-monetary inflation nature may be ineffective and cause stagnation in the secondary and tertiary sectors. If structure of economic growth seems to be weak and of low quality it might be more rational to use a part of accumulated in stabilization funds 'petrodollars' to buy promising national companies' shares, capitalization of which negatively correlates with the carbohydrates prices dynamics, instead of purchasing highly reliable securities of for- 
eign issuers. Finding and supporting the force that opposes continuing structural degradation, such as potentially competitive modern industries (not technologically integrated into the oil and gas production and export complex, yet subsidized in the medium-term by its revenues), is a task of the utmost importance for the Russian and Norwegian economies. This being so, without developing the mechanisms of incomes distribution and capital flow, natural resources-related rental payments and taxes will not ensure sustainable, economically positive structure effect.

\section{ECONOMETRIC MODEL OF INTERSECTORAL SHIFTS IN THE ECONOMIES OF RUSSIA AND NORWAY}

The following equations of secondary sector share dynamics in the Russian $(y=-0.118 x+27.24)$ and Norwegian $(y=-0.111 x+17.23)$ economies have almost identical angular coefficients describing slope of trend line (they are -0.118 and -0.111 , respectively), while the slope angle itself is small thus evidencing slow deindustrialization process. Dynamics of the primary and tertiary sector shares in both economies had slightly rising linear trend with little differing slopes, which suggests low growth rates of mentioned sectoral shares. Growth rates are similar across analogous sectors of both national economies as well as (to a lesser degree) across the primary and tertiary sectors of each country's economies.

Statistical review of mutual connections between time series of sector shares in the Russian and Norwegian economies produced the following results. Strong negative connection was identified between the primary and tertiary sectors changes: correlation coefficient of these sectors' shares $\left(r_{I, I I I}\right)$ equaled -0.8 in Russia and -0.96 in Norway. Negative value of $r_{I, I I I}$ means that the primary sector share increase causes highly probable decrease in the tertiary sector and vice versa. The correlation is strong, which enables assessment of this connection as substantial for the intersectoral shifts process. No correlation (0.12) was ob- served in the Russian economy between the primary and secondary sector shares. Such connection was not detected in Norway as well (0.07). The reason for this difference may consist in combination of the Russian industrial production high energy intensity with its latent subsidizing from the fuel-and-energy complex by purchasing energy at underestimated domestic prices (against the international background). The world oil and gas prices growth beneficially influences the widespread in Russia manufacturing enterprises involved in the first cycle raw materials' treatment increasing their global competitiveness due to rising subsidies. Negative correlation was also observed between the secondary and tertiary sector shares changes in Russia $\left(r_{I I, I I I}=-0,69\right.$, relatively strong connection) and Norway $\left(r_{I I, I-}\right.$ II $=-0,36$, weak connection). We suppose this is a consequence of the previously described features, as services are mainly non-tradable at international markets, and oil \& gas prices growth has a negative effect on the tertiary sector industries. In order to describe connections between sector shares we use linear standardized regression equation $\hat{y}=\widehat{b}_{I I} \widehat{x}_{I I}+\widehat{b}_{I I I} \widehat{x}_{I I I}$, where $\hat{y}$ - standardized primary sector share, $\widehat{b}_{I I}$ and $\widehat{b}_{I I I}$ - standardized sectoral coefficients of multiple linear regression equation, $\widehat{x}_{I I}$ and $\widehat{x}_{I I I}$ - standardized shares of secondary and tertiary sectors, respectively. For instance, coefficient $\widehat{b}_{I I I}$ of $\widehat{x}_{I I I}$ shows average change in primary sector share by tertiary sector share changing by one standard deviation $(\delta)$ and secondary sector share average remaining constant. Equation for Russia will have the following form: $\hat{y}=-0,82 \widehat{x}_{I I}-1,37 \widehat{b}_{I I I} \widehat{x}_{I I I}$. As $r_{I I I I}$ is more than $r_{I I I}$, absolute coefficient of $\hat{x}_{I I I}$ in the equation exceeds absolute coefficient of $\widehat{x}_{I I}$ ; as a result, increase of tertiary sector share by 1 standard deviation $\left(\delta_{I I I}\right)$ will cause decrease in primary sector share by $1.37 \delta_{I}$ on average (by constancy of average secondary sector share). In case of Norway, an equation takes the following form: $\hat{y}=-0,32 \widehat{x}_{I I}-1,07 \widehat{b}_{I I} \widehat{x}_{I I I}$ Here correlation between the primary and tertiary sectors is much stronger than between the primary and secondary ones, so increase 
of tertiary sector share by 1 standard deviation $\left(\delta_{I I I}\right)$ leads to mean reduction of primary sector share by $1.07 \delta_{I}$ (while the secondary sector share does not change).

Less evident (as compared to the Russian economy) reaction on the tertiary sector share change of the primary sector share in the Norwegian economy can be explained by a larger share of the primary sector in Norway, which reduces coefficient $\widehat{b}_{I I I}$. Impact of the secondary sector share changes on the primary sector share is negligible.

\section{CONCLUSIONS}

Practical aspects of using the model of national economy division into primary, secondary and tertiary sectors presented in the paper show contradictory nature of the post-industrial society development. The intention to maintain the economy's structure inherent in industrial society and to partially adjust down the high degree of dependence on natural resources exploitation resulted in considerable delay in development and introduction of complying with international standards classificators of economic activity types in some Eastern European countries. With the aim of determining common and specific elements in sectoral structural development of possessing significant industrial potential oil and gas producing countries of different degrees of market relations maturity we studied the matching process in Russia and Norway.

Correlation-regression analysis and development of linear model explaining interconnection of changes in sector shares of Russian and Norwegian economies in 2000-2014 disclosed presence of consequences of the 'Dutch Disease'. We identified most strong connection in intersectoral development of economy of Norway, which reveals an inverse relationship between the primary and tertiary sector shares. At the same time, Russian economy demonstrates an inverse relationship between the secondary and tertiary sector shares. Both national economies have two feebly pronounced trends of structural shifts determining their 'primarization' and tertiarization with further deindustrialization (however, the trend of Norwegian primary sector share is slightly declining). In Norway, correlation coefficients of the primary and secondary as well as secondary and tertiary sector shares dynamics are so small that it is likely there is no connection between the mentioned sector shares change. The same coefficients in case of Russia are big enough to consider connections represented by them in the intersectoral changes analysis.

As a reason for this distinction between economies, we consider Russian state policy of lowered prices establishment at the energy domestic market. Modeling of transformation of the Russian and Norwegian economies sectoral structure brought us to the conclusion on necessity of development and implementation of special policy that would help overcome dependency on raw materials export. A general direction of suggested policy may become governmental aid for the tertiary sector industries that are marked by creation of products with high value added and possess economically significant positive synergetic effect.

\section{LITERATURE}

Arrow, K. (1962). The Economic Implications of Learning-by-doing. Review of Economic Studies, 80, 155-174.

Belstat. (2012). National Statistical Committee of the Republic of Belarus, All-State Classification of Economic Activity (OKED). Retrived October, 21, 2015, from http://www.belstat.gov.ru/homep/ru/ klassificator.

Bhagwati, J. (1958). Immiserizing Growth: A Geometrical Note. Review of Economic Studies 25, 201-205.

Bjorvatn, K., Farzanegan, M. R. \& Schneider, F. (2012). Resource Curse and Power Balance: Evidence from Oil-Rich Countries. World Development, 40, 1308-1316.

Chenery, H. B. \& Taylor, L. J. (1968). Development patterns: Among Countries and Over Time. The Review of Economics and Statistics, 50, 391-416. 
Chenery, H. B., Robinson, S. \& Syrquin, M. (1986). Industrialization and Growth: A Comparative Study. New York: Oxford University Press.

Cheng, W. L., Sachs, J. \& Yang, X. (2004). An extended Heckscher-Ohlin model with transaction costs and technological comparative advantage. Economic Theory, 23, 671-688.

Cherif, R. (2013). The Dutch disease and the technological gap. Journal of Development Economics, 101, 248-255.

Clark, C. G. (1940). The Conditions of Economic Progress. London: Macmilla.

Dietrich, A. \& Krüger, J. J. (2010). Long-run sectoral development: Time-series evidence for the German economy. Structural Change and Economic Dynamics, 21, 111-122.

Dülger, F., Lopcu, K., Burgaç, A. \& Balli, E. (2013). Is Russia suffering from Dutch Disease? Cointegration with structural break. Resources Policy, 38, 605-612.

Echevarria, C. (1997). Changes in sectoral composition associated with economic growth. International Economic Review, 38, 431-452.

Ellman, M. (1981). Natural Gas, Restructuring and Re-Industrialization: The Dutch Experience of Industrial Policy. In Barker, T. \& Brailovsky V. (Eds.). Oil or Industry? (pp. 27-29). London: Academic Press.

Eurostat. (2013). Statistical Offices of the European Union, NACE Ped.2 - Structure and explanatory. Retrived October, 21, 2015, from http://www.circa.europa.eu/irc/ dsis/nacecpacon/info /data/en/NACE\%20 Rev\%202\%20-structure\%20+\%20 explanatory $\% 20$ notes $\% 20-\% 20$ RU.pdf.

Fisher, A. G. B. (1939). Production, primary, secondary and tertiary. Economic Record, 15, 24-38.

Fisher, A. G. B. (1952). A note on tertiary production. Economic Journal, 62, 820-834.

Fourastie, J. (1949). Le Grand Espoir du XXe Siècle: Progrès Technique, Progr's Économique, Progr's Social. Paris: Presses Universitaires de France.
Heil, H. \& Steinbach, A. (2011). Damit Deutschland vorankommt: Kompass für eine progressive Wirtschaftspolitik. Berlin: Vorwärtsbuch.

Klodt, H. (2000). Structural Change Towards Services: the German Experience. University of Birmingham.

Kuznets, S. (1971). Economic Growth of Nations: Total Output and Production Structure. Harvard University Press.

Kuznets, S. (1973). Modern economic growth: findings and reflections. The American Economic Review, 63, 247-258.

Ngai, L. R. \& Pissarides, C. A. (2007). Structural change in a multi-sector model of growth. The American Economic Review, 97, 429-443.

Opp, M. M., Sonnenschein, H. F. \& Tombazos, C. G. (2009). Rybczynski's Theorem in the HeckscherOhlin World - Anything Goes. Journal of International Economics, 79, 137-142.

Pasinetti, L. L. (1981). Structural Change and Economic Growth. Theoretical Essay on the Dynamics of the Wealth of Nations. Cambridge University Press.

Pasinetti, L. L. (1993). Structural Economic Dynamics. A Theory of the Economic Consequences of Human Learning. Cambridge University Press.

Pelzer, G., 2009. Deindustrialisierung in Deutschland. Hamburg: Verlag Dr. Kovač.

Peneder, M., Kaniovski, S. \& Dachs, B. (2000). What follows tertiarisation? Structural change and the role of knowledge-based services. The Service Industries Journal, 23, 47-66.

Romer, P. (1986). Increasing returns and longrun growth. Journal of Political Economy, 94, 1002-1037.

Rosstat. (2005). Russian Statistical Yearbook, Gross value added by branches and sectors in 2000. Retrived October, 21, 2015, from http://www.gks.ru/bgd/regl/b05_13/ IssWWW.exe/Stg/11-08.htm.

Rosstat. (2011). Russian Statistical Yearbook, Gross value added by branches and sectors in 2001. Retrived October, 21, 2015, from http://www.gks.ru/bgd/regl/b05_13/ IssWWW.exe/Stg/11-09.htm. 
Rosstat. (2012). Russian Federal State Statistics Service, All-Russian Classifier of Types of Economic Activity (OKVED). Retrived October, 21, 2015, from http://www.gks.ru/ bgd/free/b02_60/Main.htm.

Rosstat. (2013). Russian Federal State Statistics Service, Nominal volume of gross domestic product produced. Retrived October, 21, 2015, from http://www.gks.ru/ bgd/free/b.01_19/IssWWW.exe/Stg/d000/ i000010r.htm.

Rosstat. (2015). Russian Federal State Statistics Service, Gross domestic product and gross value added by kind of economic activity. Retrived October, 21, 2015, from http:// www.gks.ru/wps/wcn/connect/rosstat main/rosstat/ru/statistics/accounts/\#.

Rybczynski, T. M. (1955). Factor Endowments and Relative Commodity Prices. Economica, 22, 336-341.

Stampfl, N. S. (2011). Die Zukunft der Dienstleistungsökonomie. Momentaufnahme und Perspektiven. Berlin: Springer-Verlag.

Statistics Norway. (2005). Statistical Yearbook of Norway. Oslo: Autor.

Statistics Norway. (2006). Statistical Yearbook of Norway. Oslo: Autor.
Statistics Norway. (2007). Statistical Yearbook of Norway. Oslo: Autor.

Statistics Norway. (2008). Statistical Yearbook of Norway. Oslo: Autor.

Statistics Norway. (2009). Statistical Yearbook of Norway. Oslo: Autor.

Statistics Norway. (2011). Statistical Yearbook of Norway. Oslo: Autor.

Statistics Norway. (2013). Statistical Yearbook of Norway. Oslo: Autor.

Statistics Norway. (2015). Annual national accounts, 2014. Retrived October, 21, 2015, from http://www.ssb.no/en/ nasjonalregnskap-og-konjunkturer/ statistikker/nr/aar/2015-05-20?fane=tabel\& sort=nummer8tabel=228320\#tab-tabel.

Syrquin, M. (2010). Kuznets and Pasinetti on the study of structural transformation: Never the Twain shall meet? Structural Change and Economic Dynamics, 21, 248-257.

Wolfe, M. (1955). The concept of economic sectors. Quarterly Journal of Economics, 69, 402-420.

Young, A. (1993). Invention and bounded learning by doing. Journal of Political Economy, 101, 443-472 